\title{
Effect of Soil Physico-Chemical Properties and Plant Type on Bacterial Diversity in Semi-Arid Parts in Central Sudan. Part I: Omdurman North Region
}

\author{
Hayat Ibrahim Hassan, Hatil Hashim El-Kamali* \\ Department of Botany, Faculty of Science and Technology, Omdurman Islamic University, Omdurman, Sudan \\ Email: ${ }^{*}$ hatilhashim@gmail.com
}

Received 24 September 2015; accepted 10 October 2015; published 15 October 2015

Copyright (C) 2015 by authors and OALib.

This work is licensed under the Creative Commons Attribution International License (CC BY). http://creativecommons.org/licenses/by/4.0/

(c) (i) Open Access

\section{Abstract}

Bacterial diversity and total viable counts of bacteria of the different soil samples from two different localities in Omdurman north region-Karary and Khor Omer sub-regions-were carried out. Soil physical and chemical characteristics (pH, EC, SP, solublecations: $\mathrm{Na}, \mathrm{K}, \mathrm{Ca}, \mathrm{Mg}$ and anion $\mathrm{P}$, organic carbon, total nitrogen and soil texture) in each studied sub-regions were measured. Qualitative analysis of microorganisms isolated from the studied soil samples reveals a total of more than eight different species of bacteria, of which two are unidentified. The six species are classified under Bacillus genera. In Omdurman north region soil samples, total bacterial counts ranged from $7.5 \times 10^{3} \mathrm{cfu} \cdot \mathrm{g}^{-1}$ to $1 \times 10^{4}$ with a mean of $4 \times 10^{4} \mathrm{cfu} \cdot \mathrm{g}^{-1}$. The quantitative data on microbial population recorded in the present study were analysed using two diversity indices. High Shannon-Weiner diversity index value for bacteria was obtained in Khor Omer sub-region (1.71261). Actinomyces spp. and Streptomyces spp. were the most abundant microorganisms identified in the two sub-regions. Total bacterial count in Karary soil was positively correlated with EC $(r=0.3868)$, clay $(r=0.1412)$, sand $(r=0.5891)$ and $K(r=0.0265)$ and negatively correlated with $p H$, silt, $S P$, $\mathrm{Na}, \mathrm{P}, \mathrm{Ca}, \mathrm{Mg}, \mathrm{N}$ and $\mathrm{OC}$ whereas the total bacterial count in Khor Omer soil was positively correlated with EC $(r=0.3973)$, clay $(r=0.1966)$, silt $(r=0.2116), C a(r=0.6733), M g(r=0.586)$ and OC $(r=0.2368)$ and negatively correlated with $\mathrm{pH}$, sand, $\mathrm{SP}, \mathrm{Na}, \mathrm{K}, \mathrm{P}$ and $\mathrm{N}$. There were obvious differences in correlation coefficients among the selected criteria $37 \%$ of the total number of correlation coefficients were positively correlated between bacterial counts and soil physico-chemical properties whereas $63 \%$ of the total number were positively correlated between plant type and bacterial counts). The formulation of an appropriate national strategy in biotechnology should constitute an important, initial step towards the utilization and industrialization of microorganisms. The development of molecular techniques of microbial identification, coupled with traditional methods is promising areas for continued research.

\footnotetext{
${ }^{*}$ Corresponding author.
}

How to cite this paper: Hassan, H.I. and El-Kamali, H.H. (2015) Effect of Soil Physico-Chemical Properties and Plant Type on Bacterial Diversity in Semi-Arid Parts in Central Sudan. Part I: Omdurman North Region. Open Access Library Journal, 2: e1863. http://dx.doi.org/10.4236/oalib.1101863 


\title{
Keywords
}

\section{Microbial Diversity, Physico-Chemical Properties, Soils, Semi-Arid Region, Central Sudan}

\author{
Subject Areas: Microbiology
}

\section{Introduction}

Microorganisms play essential roles in organic matter decomposition, nutrient cycling, and plant productivity. Soil microbes mainly bacteria and fungi are concerned with all the biochemical processes which occur in soils and they play a vital role in maintaining soil productivity. It has been generally hypothesized that reduction in soil microbial diversity will result in reduction in the functional capability of soil [1].

Soil physico-chemical characteristics influence the composition of the soil microbial community, their activity and the level of microbial mass [2]. It is important to determine optimum diversities of soil microbial populations of vegetation systems for their suitable management. In order to maximize the beneficial effects of microbial activity, there is a need for greater understanding of factors influencing microbial communities and their activities. A number of secondary metabolite compounds, representing a variety of chemical structure isolated from the various microorganisms, may provide interesting leads for further industrial considerations.

The objectives of this study were: 1 ) to obtain a better understanding of the correlations between microbial population and physic-chemical properties of different soil types in the study area; 2) to study how plant type and soil type affect the microbial diversity and abundance; 3 ) to explain the differences between the tested habitats.

\section{Materials and Methods}

\subsection{Study Site Description and Soil Sampling}

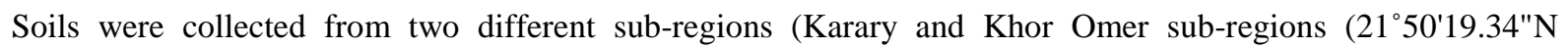
$89^{\circ} 26^{\prime} 33.84^{\prime \prime E}$ ) in the Khartoum State, in arid/semi-arid parts in Central Sudan. Soil samples were collected from $0-5 \mathrm{~cm}$ and $5-15 \mathrm{~cm}$ depths and kept in plastic bag. After collection, soil samples were brought to the laboratory and separated into two sub samples; one for bacteriological analysis that was kept in a refrigerator and the other one for the analysis of soil physico-chemical properties. Soil sampling was done in December, 2011.

\subsection{Bacteriological Analysis}

Nutrient agar medium was used for the enumeration of bacteria present in soil samples [3]. The pH was adjusted before addition of agar and sterilization. Serial dilution plate technique was used for the isolation of microorganism. One gram soil sample was diluted (1:100) with $100 \mathrm{ml}$ distilled water in a sterile conical flask and shaken well. One $\mathrm{ml}$ of this suspension was transferred to $9 \mathrm{ml}$ of sterile water for tenfold (1:10) dilution and by following serial dilution further diluted up to $10^{5}$ times. Plating in duplicate plates was made for each diluted sample. One $\mathrm{ml}$ of each of the diluted sample was taken in a sterilized petri dish by pipette. Then, molten agar medium was poured and mixed thoroughly by rotating the petri dish, first in one direction and then in the opposite direction. After setting the medium, the plates were inverted and incubated at $37^{\circ} \mathrm{C}$ for $48 \mathrm{~h}$ in an incubatorthen, the plates having well discrete colonies were selected for counting. The selected plates were placed on a colony counter (Digital colony counter, DC-8OSK1000086, Kayagaki, Japan) to count the number of colonies.

\subsection{Tests}

Motility test was determined according to Cruickshank et al., 1975 [4]. Catalase test Oxidation-Fermentation test $(\mathrm{O} / \mathrm{F})$, Oxidase test, Sugar fermentation test, Voges-Proskauer test, Nitrate reduction test, Indole production test, Urease test, Citrate utilization were determined according to Barrow and Feltham 1993 [5]. Casein hydrolysis was determined by method described by Williams and Cross, 1971 [6]. Starch hydrolysis was performed according to Collins et al., 1995 [7]. Total a viable count of bacteria was determined [8]. 


\subsection{Isolation of Streptomyces}

Isolation of Streptomyces was performed by the soil dilution plate technique [9]. In this technique; $1 \mathrm{~g}$ of each soil sample was taken in $9 \mathrm{ml}$ of sterilized distilled water in pre-sterilized test tube. Serial aqueous dilutions $\left(10^{-2}-10^{-7}\right)$ were prepared by transferring $1 \mathrm{ml}$ of the soil suspension into $9 \mathrm{ml}$ of sterilized distilled water in sterilized test tubes. Different aqueous dilutions $\left(10^{-4}-10^{-6}\right)$ of the soil suspensions were applied separately into sterilized Petri-dishes and $20 \mathrm{ml}$ of Starch-Casein Agar salt medium, $\mathrm{SCKNO}_{3}$, was added, mixed thoroughly and the plates were incubated at $28^{\circ} \mathrm{C}$ for $7-14$ days. $\mathrm{SCKNO}_{3}$ medium was prepared by dissolving $10 \mathrm{~g}$ soluble starch, $2 \mathrm{~g}$ dipotassium hydrogen ortho-phosphate, $2 \mathrm{~g}$ potassium nitrate, $2 \mathrm{~g}$ sodium chloride, $4 \mathrm{~g}$ casein, $0.05 \mathrm{~g}$ hydrated magnesium sulphate, $0.1 \mathrm{~g}$ calcium carbonate; $0.01 \mathrm{~g}$ hydrated ferric sulphate, $15 \mathrm{~g}$ agar in one liter of distilled water. The medium was sterilized by autoclaving at $121^{\circ} \mathrm{C}$ for 15 minutes. Colonies characteristic of Streptomycetaceae (rough, chalky, powdery and with earth odour) that appeared on the incubated plates were selected, repeatedly sub-cultured for purification and stored at $4^{\circ} \mathrm{C}$ onto slants of $\mathrm{SCKNO}_{3}$ medium until further examinations.

\subsection{Analysis of Soil Physico-Chemical Properties}

The $\mathrm{pH}$ of the soil was measured in a soil water suspension (1:2, soil:water). The electrical conductivity (EC) analysis was measured in the saturated extract. $\mathrm{Na}^{+}$and $\mathrm{K}^{+}$were determined photometrically. The exchangeable cations $\left(\mathrm{Ca}^{++}\right.$and $\left.\mathrm{Mg}^{++}\right)$were determined by Atomic Absorption Spectrophotometer (AAS, Perkin-Elmer, 047-1705. Saturated percentage (SP) were also determined [10]. Organic carbon content of the soil was determined byWakely and Black method (cited by Moghimi et al., [11]). Total nitrogen (\%) was determined by Kjeldahl method following extraction from $2 \mathrm{~g}$ soil with conc. $\mathrm{H}_{2} \mathrm{SO}_{4}$. The particle size analysis was carried out by the Pipette method (cited by Moghimi et al., 2013 [11]).

Once the percentage of sand, silt, and clay is measured, the soil may be assigned a textural class using the table of textural soil types (cited by Subrahmanyam and Sambamurty [12]).

\subsection{Bacterial Diversity Measures}

1) Shannon-Weiner Biodiversity Index:

$$
\text { Species diversity }(H)=-\left(P_{i}\right)\left(\log _{2} P_{i}\right)
$$

where: $P=$ the proportion of all individuals in the sample which belongs the species $i$.

2) Simpson Index: $D=1-\sum_{i=1} S\left(P_{i}\right)^{2}$

where: $D$ is the index number; $S=$ the total number of species; $P=$ the proportion of all individuals in the sample which belongs to species $i$ (cited by Subrahmanyam and Sambamurty [12]).

\section{Results and Discussion}

Eight organisms were isolated from collected soil samples; Actinomyces spp., Streptomyces spp., Bacilluslentus, Bacillus badius, Bacillus pantothenticus, Bacillus mycoides, Bacillus alvei and Bacillus sphericus. Actinomycesspp. have highest frequency in the two studied sub-regions and next are Streptomyces spp.

Microbial diversity indices can function as bio-indicator to show community stability and describing the ecological dynamic of community (and analysis of soil microbial diversity is important to evaluate the importance of perturbations in soil systems). It can also provide an early indication of changes in soil long before it can be measured by changes in organic matter [13] [14].

The diversity of soil microorganisms of the study habitat is presented in Table 1 . The Shannon-Weiner

Table 1. Diversity of microorganisms in the study area.

\begin{tabular}{ccc}
\hline Sub-region & Shannon-Weiner diversity index & Simpson diversity index \\
\hline Karary & 0.18959 & 1.050 \\
Khor Omer & 1.71261 & 2.5 \\
\hline
\end{tabular}


diversity Index value for Khor Omer sub-region (1.71261). The Simpson Index value for Khor Omer sub-region was (2.5).

An increasing interest has emerged with respect to the importance of microbial diversity in soil habitats. The extent of the diversity of microorganisms in soil is seen to be critical to the maintenance of soil health and quality, as a wide range of microorganisms is involved in important soil functions. The two main diverse of soil microbial community structure i.e. plant type and soil type.

The composition of the soil microbial community can be altered by plant species, plant diversity, vegetation type, soil type, seasonal variability in water, temperature and availability of organic substances [15].

The results concerning soil physical and chemical characteristics ( $\mathrm{pH}, \mathrm{EC}$, SP, soluble cations: $\mathrm{Na}, \mathrm{K}, \mathrm{Ca}, \mathrm{Mg}$ and anion $\mathrm{P}$, organic carbon, total nitrogen and soil texture in twodifferent studied sub-regions are presented in Table 2. The correlation effects between the soil parameters on bacterial count were studied Table 3 . The diversity of soil microorganisms of the study habitat is presented in Table 3.

The soil of Karary sub-region is predominantly loam. The $\mathrm{pH}$ of soil samples ranged from 7.40 to 7.70 . The EC values varied from $0.70-2.57 \mathrm{mmohs} / \mathrm{cm}$. The total nitrogen was in range $0.035-0.065$. Organic carbon range between $0.46 \%$ and $0.64 \%$. C: $\mathrm{N}$ ratio range between $7: 1$ and $14: 1$. The SP ranged from $23.4 \%-38.9 \%$. Sodium contents ranges between 1.268 and $3.721 \mathrm{Meq} / \mathrm{L}$. As for K it varies between 0.142 and $0.379 \mathrm{Meq} / \mathrm{L}$. Calcium contents was found to vary between 4.0 - $19 \mathrm{Meq} / \mathrm{L}$. Magnesium contents was found to vary between 2.0 and $10.0 \mathrm{Meq} / \mathrm{L}$. P contents ranged between 3.2888 and $3.636 \mathrm{ppm}$ (Table 2). Total bacterial count was positively correlated with EC $(r=0.3868)$, clay $(r=0.1412)$, sand $(r=0.5891)$ and $K(r=0.0265)$ and negatively correlated with $\mathrm{pH}$, silt, $\mathrm{SP}, \mathrm{Na}, \mathrm{P}, \mathrm{Ca}, \mathrm{Mg}, \mathrm{N}$ and OC (Table 3).

The soil of Khor Omer sub-region is predominantly loam. The $\mathrm{pH}$ of soil samples ranged from 7.21 to 7.85. The EC values varied from $0.50-0.90 \mathrm{mmohs} / \mathrm{cm}$. The total nitrogen was in range $0.028-0.168$. Organic carbon range between $0.16 \%$ and $0.68 \%$. C:N ratio range between 3:1 and 23:1. The SP ranged from $23.9 \%$ 37.7\%. Sodium contents ranges between 2.047 and $31.4 \mathrm{Meq} / \mathrm{L}$. As for K it varies between 0.109 and 0.247 $\mathrm{Meq} / \mathrm{L}$. Calcium contents was found to vary between $4.0-27 \mathrm{Meq} / \mathrm{L}$. Magnesium contents was found to vary between 3.0 and $20 \mathrm{Meq} / \mathrm{L}$. P contents ranged between 3.288 and $3.3636 \mathrm{ppm}$ (Table 2). Total bacterial count was positively correlated with EC $(r=0.3973)$, clay $(r=0.1966)$, silt $(r=0.2116)$, Ca $(r=0.6733), \mathrm{Mg}(r=$ $0.586)$ and $\mathrm{OC}(\mathrm{r}=0.2368)$ and negatively correlated with $\mathrm{pH}$, sand, SP, Na, K, P and N (Table 3).

The results showed that the sandy clay loam, sandy loam, and loam showed the highest bacterial populations (Table 2 and Table 4). Previous studies showed that soil types influence the structure of microbial community, especially bacterial population among soils of different textures [16] [17]. Possible explanation for the higher number of bacteria in soil with caly contents was documented by Carney and Matson 2005 [18], who mentioned that fine textured soils support more microbial biomass than coarse textured soils. The distribution of microorganisms in various soil textures might be related to soil moisture and nutrient contents as explained by Heritage et al., 2003 [19], who stated that sandy soils could not retain water very well and drain very quickly. In contrast, clay loam preserves water and hold nutrients for longer period.

From the studied region (the two sub-regions) collected soils, four different textural soil classes (clay loam, sandy clay loam, loam, sandy loam) were detected (Table 2). Data of soil $\mathrm{pH}$ values showed some differences among different soil textures. In Khor Omer sub-region, the lowest value $(\mathrm{pH}=7.21)$ was recorded in clay loam and the highest one $(\mathrm{pH}=7.85)$ in loam (Table 2). The highest value of soil organic carbon contents were recorded in the texture soils loam whereas the lowest contents were in clay loam and sandy clay loam. These differences were documented previously by Silver et al., [20] who found that soil texture plays a key role in below ground $\mathrm{C}$ storage in soil ecosystems and strongly influences nutrient availability and retention, particularly in fine textural soils. Matus et al., [21], observed that soil organic carbon tends to be associated with the fine fraction of soils and it was significantly three times in clay-rich soils than coarse soils. Fine texture soil shows more stable aggregates, which in turn may act as a media of greater amount of organic carbon and total nitrogen contents [22].

The higher bacterial counts observed in Acacia tortilis ssp. spirocarpa rhizosphere in the soil of Karary sub-region and in Panicum turgidum rhizospherein the soil of Khor Omer sub-region. This could be to better availability of nutrients and environmental conditions, which favored their growth.

Bacterial count tend to decrease with increase in soil depth. Decrease in the bacterial counts with increasing soil depth could be related to the organic carbon content of the soil as nutrients are declining with the increase in soil depth. The higher bacterial counts at the surface layer might be due to the presence of litters, twigs, herbs 


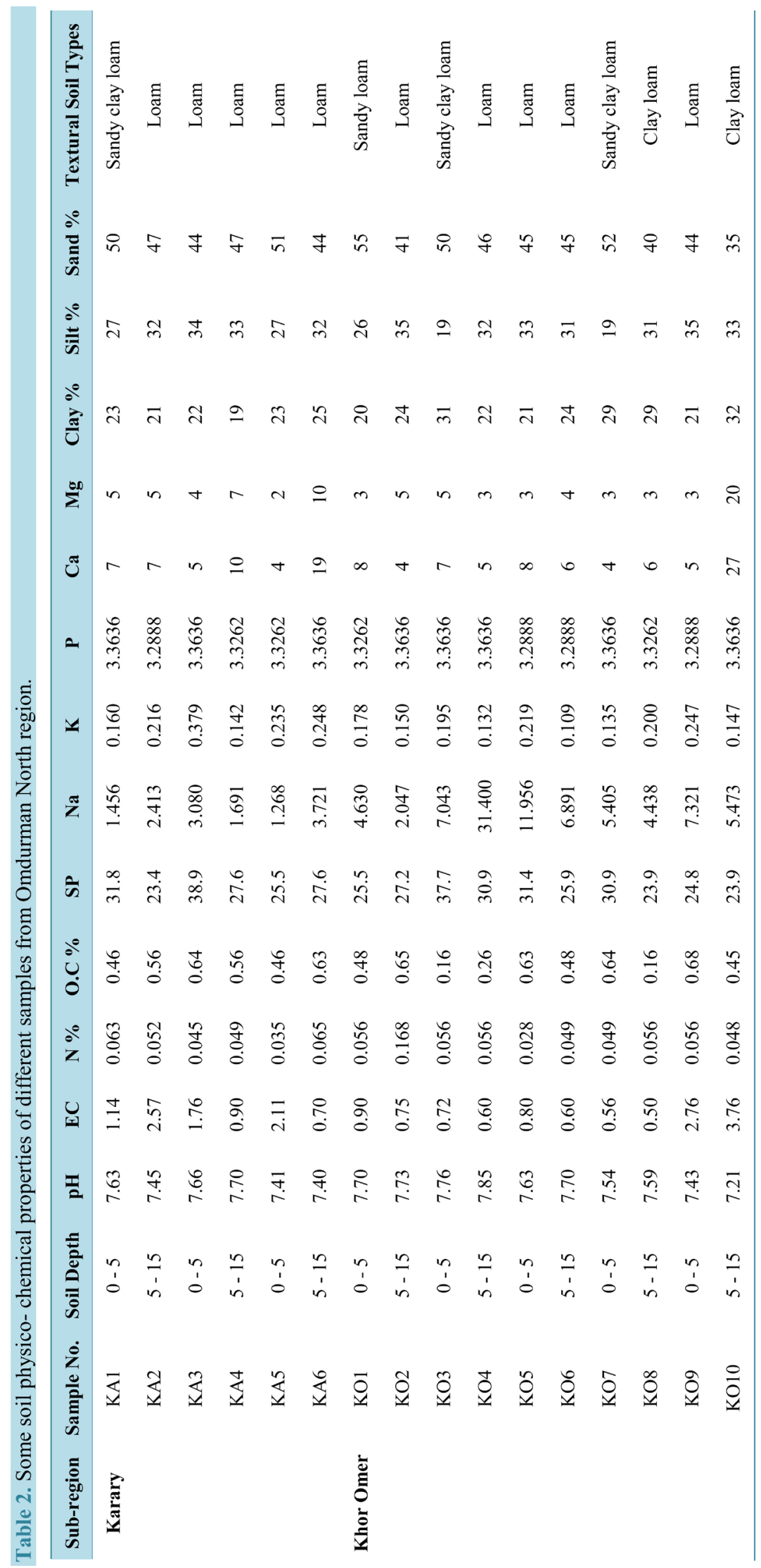


Table 3. Correlation coefficients of the physico-chemical properties with the viable bacterial count (cfu $\mathrm{g}^{-1}$ soil) in Karary and Khor Omer sub-regions.

\begin{tabular}{|c|c|c|c|c|c|c|c|c|c|}
\hline Sub-region & $\begin{array}{l}\text { Soil physico- } \\
\text { chemical } \\
\text { properties }\end{array}$ & $\mathbf{R}$ & $\mathbf{R}^{2}$ & Correlation & $\begin{array}{l}\text { Sub- } \\
\text { region }\end{array}$ & $\begin{array}{l}\text { Soil physico- } \\
\text { chemical } \\
\text { properties }\end{array}$ & $\mathbf{R}$ & $\mathbf{R}^{2}$ & Correlation \\
\hline \multirow[t]{13}{*}{ Karary } & $\mathrm{pH}$ & -0.4698 & 0.2207 & -ve & Khor Omer & $\mathrm{pH}$ & -0.5191 & 0.2695 & - ve \\
\hline & EC & 0.3868 & 0.1496 & +ve & & EC & 0.3973 & 0.1578 & +ve \\
\hline & Clay & 0.1412 & 0.0199 & +ve & & Clay & 0.1966 & 0.0387 & +ve \\
\hline & Silt & -0.6572 & 0.4319 & Moderate-ve & & Silt & 0.2116 & 0.0448 & +ve \\
\hline & Sand & 0.5891 & 0.347 & Moderate +ve & & Sand & -0.3897 & 0.1519 & - ve \\
\hline & SP & -0.3204 & 0.1027 & - ve & & SP & -0.0614 & 0.0038 & - ve \\
\hline & $\mathrm{Na}$ & -0.5075 & 0.2576 & Moderate-ve & & $\mathrm{Na}$ & -0.0097 & 0.0001 & - ve \\
\hline & $\mathrm{K}$ & 0.0265 & 0.0007 & Weak +ve & & K & -0.0933 & 0.0087 & Weak-ve \\
\hline & $\mathrm{P}$ & -0.2006 & 0.0402 & Weak -ve & & $\mathrm{P}$ & -0.1895 & 0.0359 & Weak-ve \\
\hline & $\mathrm{Ca}$ & -0.4224 & 0.1784 & Weak -ve & & $\mathrm{Ca}$ & 0.6733 & 0.4533 & Moderate +ve \\
\hline & $\mathrm{Mg}$ & -0.6293 & 0.396 & Moderate-ve & & Mg & 0.586 & 0.3434 & Moderate +ve \\
\hline & $\mathrm{N}$ & -0.718 & 0.5155 & Moderate-ve & & $\mathrm{N}$ & -0.4331 & 0.1876 & Weak -ve \\
\hline & O.C & -0.5753 & 0.331 & Moderate-ve & & O.C & 0.2368 & 0.0561 & Weak +ve \\
\hline
\end{tabular}

Table 4. Total bacterial count of different soil samples from omdurman north region.

\begin{tabular}{|c|c|c|c|c|c|}
\hline Sub-region & Sample No. & Plant sample & Soil depth & Bacterial count (CFU/g) & Organisms \\
\hline \multirow[t]{6}{*}{ Karary } & KA1 & Acacia tortilis ssp. Radiana & $0-5$ & $1.25 \times 10^{4}$ & $\begin{array}{l}\text { Bacillus sphericus } \\
\text { B. badius } \\
\text { B. lentus } \\
\text { B. panthothticus } \\
\text { Actinomyces spp. } \\
\text { Streptomyces spp. }\end{array}$ \\
\hline & KA2 & A. tortilis ssp. radiana & $5-15$ & $7.5 \times 10^{3}$ & $\begin{array}{l}\text { B. sphericus } \\
\text { B. lentus } \\
\text { Actinomyces spp. } \\
\text { Streptomyces spp. }\end{array}$ \\
\hline & KA3 & Corchorus depressus & $0-5$ & $7.5 \times 10^{3}$ & $\begin{array}{l}\text { B. sphericus } \\
\text { B. mycoides } \\
\text { B. lentus } \\
\text { B. panthothticus } \\
\text { Actinomyces spp. } \\
\text { Streptomyces spp. }\end{array}$ \\
\hline & KA4 & C. depressus & $5-15$ & $1 \times 10^{4}$ & $\begin{array}{l}\text { B. sphericus } \\
\text { B. badius } \\
\text { B. lentus } \\
\text { B. panthothticus } \\
\text { Actinomyces spp. } \\
\text { Streptomyces spp. }\end{array}$ \\
\hline & KA5 & Acacia tortilis ssp. Spirocarpa & $0-5$ & $1.5 \times 10^{6}$ & $\begin{array}{l}\text { B. sphericus } \\
\text { B. badius } \\
\text { B. lentus } \\
\text { Actinomyces spp. } \\
\text { Streptomyces spp. }\end{array}$ \\
\hline & KA6 & A. tortilis ssp. spirocarpa & $5-15$ & $1.5 \times 10^{3}$ & $\begin{array}{l}\text { B. sphericus } \\
\text { B. lentus } \\
\text { B. panthothticus } \\
\text { Actinomyces spp. } \\
\text { Streptomyces spp. }\end{array}$ \\
\hline
\end{tabular}




\section{Continued}

\begin{tabular}{|c|c|c|c|c|c|}
\hline \multirow[t]{10}{*}{ Khor Omer } & KO1 & Balanites aegyptiaca & $0-5$ & $6.5 \times 10^{3}$ & $\begin{array}{l}\text { B. sphericus } \\
\text { B. badius } \\
\text { B. mycoides } \\
\text { B. panthothticus } \\
\text { Actinomyces spp. } \\
\text { Streptomyces spp. }\end{array}$ \\
\hline & $\mathrm{KO} 2$ & B. aegyptiaca & $5-15$ & $6 \times 10^{3}$ & $\begin{array}{l}\text { B. sphericus } \\
\text { B. badius } \\
\text { B. lentus } \\
\text { Actinomyces spp. } \\
\text { Streptomyces spp. }\end{array}$ \\
\hline & KO3 & Acacia ehrenbergiana & $0-5$ & $1.25 \times 10^{4}$ & $\begin{array}{l}\text { B. sphericus } \\
\text { B. alvei } \\
\text { B. lentus } \\
\text { Actinomyces spp. } \\
\text { Streptomyces spp. }\end{array}$ \\
\hline & KO4 & A. ehrenbergiana & $5-15$ & $1.5 \times 10^{4}$ & $\begin{array}{l}\text { B. sphericus } \\
\text { B. alvei } \\
\text { B. lentus } \\
\text { B. panthothticus } \\
\text { Actinomyces spp. } \\
\text { Streptomyces spp. }\end{array}$ \\
\hline & KO5 & Panicum turgidum & $0-5$ & $1.25 \times 10^{5}$ & $\begin{array}{l}\text { B. sphericus } \\
\text { B. mycoides } \\
\text { B. lentus } \\
\text { B. panthothticus } \\
\text { Actinomyces spp. } \\
\text { Streptomyces spp. }\end{array}$ \\
\hline & KO6 & P. turgidum & $5-15$ & $6 \times 10^{4}$ & $\begin{array}{l}\text { Bacillus mycoides } \\
\text { B. lentus } \\
\text { B. panthothticus } \\
\text { Actinomyces spp. } \\
\text { Streptomyces spp. }\end{array}$ \\
\hline & KO7 & Citrullus colocynthis & $0-5$ & $4 \times 10^{4}$ & $\begin{array}{l}\text { B. sphericus } \\
\text { B. badius } \\
\text { B. lentus } \\
\text { Actinomyces spp. } \\
\text { Streptomyces spp. }\end{array}$ \\
\hline & KO8 & C. colocynthis & $5-15$ & $1.4 \times 10^{4}$ & $\begin{array}{l}\text { B. sphericus } \\
\text { B. lentus } \\
\text { Actinomyces spp. } \\
\text { Streptomyces spp. }\end{array}$ \\
\hline & KO9 & Maerua crassifolia & $0-5$ & $6 \times 10^{3}$ & $\begin{array}{l}\text { B. sphericus } \\
\text { B. mycoides } \\
\text { B. lentus } \\
\text { Actinomyces spp. } \\
\text { Streptomyces spp. }\end{array}$ \\
\hline & KO10 & M. crassifolia & $5-15$ & $1.25 \times 10^{5}$ & $\begin{array}{l}\text { B. sphericus } \\
\text { B. mycoides } \\
\text { B. lentus } \\
\text { Actinomyces spp. } \\
\text { Streptomyces spp. }\end{array}$ \\
\hline
\end{tabular}

and tree canopy which render a moist environment in the soil and favor high microbial activity and hence high microbial populations [23].

The huge diversity characterizing the Bacillus species at the taxonomic level, is also noticeable for their metabolic features. Development of microbial bioactive compounds technology it depends basically of four steps: isolation and selection of strains with higher activity, fermentation process optimization, application of an appropriate method to cell separation and development of formulations. These bacteria are able to produce a wide 
range of secondary metabolites with very different natures and structures and displaying broad spectra of activities. The metabolites including antibiotics, pigments, toxins, growth promoters (animals and plants) pheromones, enzyme inhibitors and other bioactive compounds [24]. In general, these metabolites serve as: 1) competitive weapons used against other bacteria, fungi, plants insects; 2) metal transporting agents; 3) symbiosis effectors between microbes and plants, insects; 4) sexual hormones; and 5) as differentiation factors [25].

Secondary metabolite compounds expands the potential industrial importance of the genus Bacillus [26]. Bacteria from the genus Bacillus are among the entomopathogenic microorganisms most commonly used as biocontrol agents. Among them Bacillus sphaericusis used in vector contol programs of endemic diseases such as dengue, malaria and filariasis. Because they are spore-former bacteria and produce toxins highly specific to target insects are better suited to industrial production and field application. The study of mosquitocidal bacteria from wild resources may provide interesting leads for further industrial considerations.

\section{Conclusion}

There is a need for greater understanding of physical, chemical, biochemical and biological factors influencing abundance and diversity on microbial habitats. Our results show that field data interpretation of soils properties is difficult, particularly when several factors exerting an influence on microbial communities are involved.

\section{References}

[1] Giller, K.E., Beare, M.H., Lavelle, R. and Izac, A. (1997) Agricultural Intensification. Soil Biodiversity and Agroecosystem Function. Applied Soil Ecology, 6, 3-16. http://dx.doi.org/10.1016/S0929-1393(96)00149-7

[2] Dick, R.P. (1994) Soil Enzyme Activities as Indicators of Soil Quality. In: Doran, J.W., Coleman, D.C., Bezdicek, D.F. and Stewart, B.A., Eds., Defining Soil Quality for a Sustainable Environment, Soil Science Society of America.

[3] Cheesbrough, M. (1984) Culture Media. In: Medical Laboratory Manual for Tropical Countries, Tropical Health Technology and Butterworth-Heineman, Cambridge, Vol. III.

[4] Cruickshank, R. (1975) Medical Microbiology: A Guide to Diagnosis and Control of Infection. E and S Livingston Ltd., Edinburgh and London, 888.

[5] Barrow, G.H. and Feltham, R.K.A. (1993) Cowan and Steel's Manual for Identification of Medical Bacteria. 3rd Edition, Cambridge University Press, Cambridge, 331. http://dx.doi.org/10.1017/CBO9780511527104

[6] Williams, S.T. and Cross, T. (1971) Actinomycetes. In: Booth, C., Eds., Methods in Microbiology, Academic Press, London.

[7] Collins, C.H., Lyne, P.M. and Grange, J. (1995) Collins and Layne’s Microbiological Methods. Butterworth-Heinemann, London.

[8] Benson, T. (2001) Microbiological Applications Laboratory Manual in General Microbiology. 8th Edition, The McGraw-Hill, New York.

[9] You, K.M. and Park, Y.K. (2004) A New Method for the Selective Isolation of Actinomycetes from Soil. Biotechnology Techniques, 10, 541-546.

[10] Richards, L.A. (1954) Diagnosis and Improvement of Saline and Alkali Soils. US Dept. Agr. Handbook 60 US Gov. Printing Office, Washington DC.

[11] Moghimi, A.H., Hamdan, J., Shamshuddin, J., Samsuri, A.W. and Abtahi, A. (2013) Physicochemical Properties and Surface Charge Characteristics of Arid Soils in Southern Iran. Applied and Environmental Soil Science, 2013, Article ID: 252861. http://dx.doi.org/10.1155/2013/252861

[12] Subrahmanyam, N.S. and Sambamurty, A.V.S.S. (2000) Ecology. Narosa Publishing House, New Delhi, 172.

[13] Atlas, R.M. (1984) Diversity of Microbial Communities. In: Marshall KC., Ed., Advances in Microbial Ecology, Plerum Press, New York, 1-47. http://dx.doi.org/10.1007/978-1-4684-8989-7_1

[14] Turco, R.F., Kennedy, A.C. and Jawson, M.D. (1994) Microbial Indicators of Soil Quality. In: Doran, J.W., Coleman, D.C., Bezdicek, D.F. and Stewart, B.A., Eds., Defining Soil Quality for a Sustainable Environment, Soil Science Society of America Special Publication No. 35, SSSA, Madison, 73-90.

[15] McCulley, R.L. and Burke, L.C. (2004) Microbial Community Composition across the Great Plains: Landscape versus Regional Variability. Soil Science Society of America Journal, 68, 106-115. http://dx.doi.org/10.2136/sssaj2004.1060

[16] Garbeva, P., van Veen, J.A. and Elsas, J.D. (2004) Microbial Diversity in Soil: Selection of Microbial Populations by Plant and Soil Type and Implications for Disease Suppressiveness. Annual Review of Phytopathology, 42, $243-270$. http://dx.doi.org/10.1146/annurev.phyto.42.012604.135455 
[17] Fang, M., Kremer, R.J., Motavalli, P.P. and Davis, G. (2005) Bacteria Diversity in Rhizospheres of Nontransgenic and Transgenic Corn. Applied and Environmental Microbiology, 71, 4132-4136. http://dx.doi.org/10.1128/AEM.71.7.4132-4136.2005

[18] Carney, K.M. and Matsu, P.A. (2005) Plant Communities, Soil Microorganisms, and Soil Carbon Cycling: Does Altering the World Belowground Matter to Ecosystem Functioning? Ecosystems, 8, 928-940. http://dx.doi.org/10.1007/s10021-005-0047-0

[19] Heritage, J., Evans, E. and Killington, R. (2003) Microbiology in Action. Cambridge University Press, Cambridge.

[20] Silver, W., Neff, J., McGroddy, M., Veldkamp, E., Keller, M. and Cosme, R. (2000) Effects of Soil Texture on Belowground Carbon and Nutrient Storage in Lowland. Amazonian Forest Ecosystem. Ecosystems, 3, 193-209. http://dx.doi.org/10.1007/s100210000019

[21] Matus, F.J., Christopher, H.L. and Christian, R.M. (2008) Effect of Soil Texture, Carbon Input Rates, and Litter Quality on Free Organic Matter and Nitrogen Mineralization in Chilean Rain Forest and Agricultural Soils. Communications in Soil Science and Plant Analysis, 39, 187-201. http://dx.doi.org/10.1080/00103620701759137

[22] Raiesi, F. (2006) Carbon and N Mineralization as Affected by Soil Cultivation and Crop Residue in a Calcareous Wetland Ecosystem in Central Iran. Agriculture, Ecosystems \& Environment, 112, 13-20. http://dx.doi.org/10.1016/j.agee.2005.07.002

[23] Ndaw, S.M., Gama-Rodrigues, A.C., Gama-Rodrigues, E.F., Sales, K.R. and Rosado, A.S. (2009) Relationship between Bacterial Diversity, Microbial Biomass, and Litter Quality in Soils under Different Plant Covers in Northern Rio de Janeiro State, Brazil. Canadian Journal of Microbiology, 55, 1089-1095. http://dx.doi.org/10.1139/W09-066

[24] Stein, T. (2005) Bacillus subtilis Antibiotics: Structures, Synthesis and Specific Functions. Molecular Microbiology, 56, 845-857. http://dx.doi.org/10.1111/j.1365-2958.2005.04587.x

[25] Demain, A.L. and Fang, A. (2000) The Natural Functions of Secondary Metabolites. In: Fiechter, A., Ed., History of Modern Biotechnology I, Advances in Biochemical Engineering/Biotechnology, Vol. 69, Springer, Berlin, 1-39. http://dx.doi.org/10.1007/3-540-44964-7 1

[26] Sansinenea, E. and Ortiz, A. (2011) Secondary Metabolites of Soil Bacillus Spp. Biotechnology Letters, 33, $1523-1538$. http://dx.doi.org/10.1007/s10529-011-0617-5 